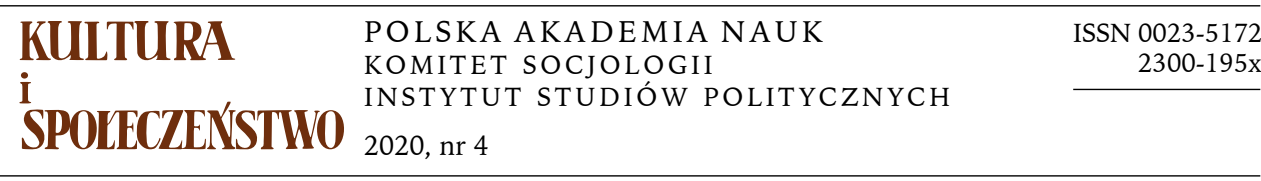
$\begin{array}{llllllll}A & R & T & Y & K & U & Ł & Y\end{array}$
I
$\begin{array}{llllllll}\mathrm{R} & \mathrm{O} & \mathrm{Z} & \mathrm{P} & \mathrm{R} & \mathrm{A} & \mathrm{W} & \mathrm{Y}\end{array}$

KRZYSZTOF MALICKI

Uniwersytet Rzeszowski

\title{
MIĘDZY KANONEM A ARCHIWUM — O SYSTEMATYZACJI I KLASYFIKACJI MIEJSC PAMIĘCI
}

\section{UWAGI WSTĘPNE}

Kiedy u schyłku XX wieku analitycy procesów społeczno-kulturowych diagnozowali fenomen „obsesji na punkcie pamięci” (Huyssen 1995, s. 253), niewiele symptomów wskazywało na to, że dwie-trzy dekady później zjawisko to w niczym nie utraci na sile i atrakcyjności dla kolejnego pokolenia badaczy. Ponadnormatywne zainteresowanie problematyką przeszłości to nadal jedno $z$ częściej omawianych zagadnień, nie tylko na gruncie studiów pamięcioznawczych. Znamienne jest przy tym, iż mimo kilku dekad intensywnych prac nad teorią i realizacją przedsięwzięć empirycznych $\mathrm{w}$ zakresie tej problematyki w fenomenie zainteresowania przeszłością nadal trudno doszukać się zbyt wielu wspólnych pojęciowych mianowników. Badacze sami przyznają, że pojęcie pamięci zbiorowej jest „elastyczną hybrydą pojęciową" (Saryusz-Wolska, Traba 2014, s. 16), a na obszarze studiów pamięcioznawczych panuje „pojęciowy i terminologiczny chaos" (Szacka 2006, s. 33), oznaczający brak zgodności co do wielu kluczowych definicji. Lektura prac z obszaru memory studies pełna jest pojęć, których twórcy starają się oddać fenomen fascynacji przeszłością bądź jej przedmiotowego wykorzystywania w celach politycznych. Są to pojęcia takie jak: memory boom (Huyssen 1995), mnemonic turn (Bachmann-Medick 
2012), polityka pamięci (Nijakowski 2008), by wymienić jedynie najważniejsze. Będąc świadomym uwikłania refleksji poświęconej pamięci w domeny badawcze historii, psychologii czy socjologii, Jacques Le Goff zauważył celnie, że pojęcie pamięci jest usytuowane „na skrzyżowaniu dróg” (Le Goff 2007, s. 101). Wydaje się, że dotychczas skrzyżowania tego nie objaśniły w pełni precyzyjne drogowskazy.

Problem definicyjno-pojęciowych nieścisłości dotyczy nie tylko przypadku pamięci zbiorowej, lecz także wielu innych zjawisk kulturowych na gruncie nauk humanistycznych i społecznych. Terminologicznej niespójności w obszarze memory studies niewątpliwie sprzyja interdyscyplinarność tej dziedziny badań. Liczba studiów poświęconych problematyce pamięci zbiorowej systematycznie rośnie, a zainteresowanie nią przejawiają nie tylko socjologowie, lecz także antropolodzy, literaturoznawcy, filozofowie, psycholodzy, politolodzy, a nawet prawnicy. W tej sytuacji badania pamięci społecznej stają się przedsięwzięciem nieparadygmatycznym, transdyscyplinarnym i zdecentralizowanym (Olick, Robbins 2014, s. 101). Pamięć zbiorowa stała się przestrzenią badawczą, na której zetknęli się przedstawiciele wielu nauk, które rzadko podejmują ze sobą dialog przynoszący owoce, wykuwany w praktyce badań terenowych zbudowanych na uzgodnieniach w sferze definicji i teorii. Ten fakt jest coraz częściej dostrzegany. Towarzyszy temu sceptycyzm co do możliwości godzenia różnych terminologii i metodologii badań, łączenia z sukcesem pracy osób reprezentujących odmienne dyscypliny. Źródło niepowodzeń widzi się w tym, że społeczne atrybuty pamięci są odmiennie eksponowane przez różne nauki, w wyniku czego ustalenia, choćby w sferze terminologii, stają się niemożliwe (Kaźmierska 2012, s. 43). „Owo wyimaginowane grono uczonych pisze o badaczach pamięci reprezentujących różne nauki Magdalena Saryusz-Wolska (2011, s. 22) - nie tylko prawie nigdy się nie spotka, ale też ich prace rzadko wchodzą ze sobą w realny dialog".

Podejmuję tu jeden $z$ aspektów problematyki pamięci zbiorowej miejsca pamięci. Celem moim jest refleksja nad możliwością klasyfikacji i systematyzacji różnorodnych ich form. A także wpisanie ich w cykl stadiów, w których istnieją od chwili zamysłu i intencji poprzedzającej powołanie materialnej formy pamięci po jej unicestwienie i zatarcie w świadomości zbiorowości. Choć miejsce pamięci jest „nadużywanym w ostatnim czasie pojęciem" (Hahn, Traba 2015, s. 9), stanowi jedno z głównych odniesień dla niemal każdego przedsięwzięcia, które za cel stawia sobie eksplorację problematyki pamięci zbiorowej. To właśnie miejscom pamięci poświęcono największe europejskie projekty pamięcioznawcze, od francuskiego Lieux de mémoire (Nora 1984-1992), przez niemieckie Deutsche 
Erinnerungsorte (François, Schulze 2001), Polsko-niemieckie miejsca pamięci (Traba, Hahn 2013-2015), Polskie miejsca pamięci (Bednarek, Korzeniewski 2014), Węzły pamięci niepodległej Polski (Najder i in. 2014).

Analiza jednej $z$ fundamentalnych prac poświęconych kulturze pamięci - Modi memorandi (Saryusz-Wolska, Traba 2014) — wskazuje na istotną rangę zagadnienia miejsc pamięci w całokształcie rozważań nad kulturą pamięci, których problematyka przewija się w licznych hasłach i jeszcze liczniejszych odnośnikach $\mathrm{w}$ hasłach pokrewnych. Za sprawą tego dzieła oraz czterotomowej publikacji wieńczącej wspomniany projekt poświęcony polsko-niemieckim miejscom pamięci niewątpliwie powstały „solidne fundamenty teoretyczne" (Stryjek 2014, s. 211). Wydaje się jednak, że proces systematyzacji pojęć $\mathrm{w}$ omawianym obszarze problemowym bynajmniej się nie zakończył. Przybywają nowe, nie zawsze precyzyjne terminy, niektórym nadaje się dodatkowe znaczenia, co skutkuje „terminologiczną inflacją" (Wawrzyniak 2014, s. 348). Modyfikowane lub tworzone na nowo pojęcia nierzadko stanowią problem dla badaczy terenowych, czyniąc ich bezradnymi w poszukiwaniu wskaźników pojęć zbyt nieostrych lub/i zawierających zbyt wiele desygnatów. Dlatego podstawą przedstawionych tu propozycji klasyfikacji są teoretyczne ujęcia wyrażone w projektach Nory oraz twórców Polsko-niemieckich miejsc pamięci, a także w koncepcji pamięci funkcjonalnej i magazynującej / kanonu i archiwum Aleidy Assmann.

Pojęcie „miejsca pamięci” jest używane w języku potocznym oraz literaturze poświęconej kwestii materialnych upamiętnień przeszłości i cechuje się wyjątkową wieloznacznością. Niezwykłą karierę rozpoczęło za sprawą dzieła Pierre Nora Lieux de mémoire. Niewiele publikacji w równie wielkim stopniu przyczyniło się do „pamięciowego przewrotu”. Nora zwrócił uwagę, że miejsca pamięci mogą istnieć $\mathrm{w}$ postaci wyobrażonej jako szeroka gama zinstytucjonalizowanych postaci zbiorowych wspomnień przeszłości. Dlatego miejscem pamięci jest zarówno archiwum, bitwa pod Verdun, słownik Larousse'a, jak i wieża Eiffla oraz 14 Lipca. Zamierzeniem Nory nie była celebracja „miejsc pamięci” rozumianych jako terytorialne obszary naznaczone symbolicznie. Choć ta oryginalna koncepcja w założeniu miała dotyczyć „historii antyupamiętnieniowej” (Nora 2002a, s. 4687), paradoksalnie znacząco przyczyniła się do wzmożenia procesu upamiętnień nazwanego później „epoką upamiętniania” (Żakowski 2002, s. 59). Nora (2002b, s. 23) zwrócił także uwagę, iż „miejsca pamięci istnieją dlatego, że nie istnieją już środowiska będące nośnikiem pamięci". Kreowanie miejsc pamięci stanowi konsekwencję zerwania $\mathrm{z}$ pamięcią w życiu codziennym: „zamieszkując wciąż pośród naszych wspomnień - pisze Nora (2002b, s. 24) - nie musielibyśmy uświęcać miejsc z nimi związanych". 
Choć propozycję Nory trudno uznać za precyzyjną, późniejsza recepcja jego pracy w naukach społecznych zapoczątkowała wzmożone zainteresowanie problematyką miejsc pamięci, wskazała bowiem na potencjał w niej zawarty i możliwości refleksji nad pamięcią zbiorową poprzez pryzmat miejsc, w których znajduje ona swe zakotwiczenie. Kolejne europejskie projekty stawiające sobie za przedmiot badania miejsca pamięci (m.in. Włochy, Holandia, Austria) bez wyjątków nawiązywały do koncepcji Nory (Kończal 2013).

Przykład Polskich miejsc pamięci (Bednarek, Korzeniewski 2014) pokazuje, że nawet próba odejścia od Nory ostatecznie oznacza przyjęcie przez redaktorów perspektywy wyrażonej definicją nawiązującą do jego idei, W myśl której miejscem pamięci są ,zdarzenia i postacie z przeszłości oraz wytwory kulturowe, których zwerbalizowany opis komunikuje dwojakie stany rzeczy: wartości oraz tożsamość zbiorowości" (Szpociński 1983, s. 134). Narodowe ramy tego projektu — odróżniające go od projektu Polsko-niemieckich miejsc pamięci - obejmują jednakże tematy stosunkowo dobrze utrwalone w świadomości społecznej, najczęściej funkcjonujące w ścisłym kanonie kulturowym wspólnoty. Pytanie, jakie musi się pojawić, dotyczy szerszego spektrum istniejących materialnie lub wyobrażonych miejsc pamięci, znajdujących się poza upamiętnianym na różne sposoby kanonem pamięci zbiorowości, a często również poza obszarem pamięci funkcjonalnej.

Jedno z najważniejszych i najbardziej interesujących pytań dotyczy kwestii klasyfikacji istniejących realnie lub metaforycznie miejsc pamięci, które w przestrzeni społecznej generują emocje, kontrowersje czy konflikty lub całkowicie nie są identyfikowane $z$ jakąkolwiek przeszłością i traktowane jako mniej lub bardziej interesujący element pejzażu danej wspólnoty. Na potrzeby analizy „miejsca pamięci” będę tu rozumiał nie tylko $\mathrm{w}$ tradycyjnym znaczeniu jako obszary związane $z$ ważnymi wydarzeniami (lub postaciami) z przeszłości, na różnorodny sposób upamiętnionymi w materialnej postaci (pomnik, tablica pamiątkowa, muzeum), lecz znacznie szerszej - także jako nie zawsze upamiętnione materialnie i określone geograficznie „wyimaginowane fenomeny historyczne: zdarzenia i miejsca topograficzne, (wyobrażone i rzeczywiste) postaci, artefakty, symbole" (Hahn, Traba 2015, s. 18). Odwołanie się w tym miejscu do rozumienia zaproponowanego przez autorów Polsko-niemieckich miejsc pamięci jest nieprzypadkowe. Nawiązuje ono do koncepcji Nory, choć odrzuca jego sztywne narodowe ramy. Twórcy tego projektu wychodzą ze słusznego założenia, że istnieją paralelne miejsca pamięci dla różnych narodów, czyniąc przy tym znamienną uwagę: „Sam opis miejsc pamięci to za mało. 
Rozpoznanie ich znaczenia dla tożsamości wymaga nieustannego ich badania pod kątem pełnienia tej funkcji” (Hahn, Traba 2015, s. 18). Dalej podażam tropem tego zalecenia.

\section{PARADOKSY UPAMIĘTNIANIA}

Istniejący pomnik, tablica pamiątkowa lub instytucja muzeum często bywają traktowane jako zwieńczenie lub finał procesu upamiętniania. Tymczasem dla badacza nierzadko najbardziej interesujące jest to, co powstanie materialnej formy pamięci poprzedza lub co dzieje się po unicestwieniu tej formy lub przejściu jej na peryferie społecznego zainteresowania $z$ jej przekazem. Burzliwe bywają historie powstawania miejsc pamięci, całkowita cisza towarzyszy likwidacji wielu z nich. Występujące $\mathrm{w}$ literaturze przedmiotu klasyfikacje miejsc związanych z pamięcią lub szerzej „nośników pamięci historycznej” (Kula 2002) - najczęściej obejmują realnie istniejące pomniki, segregowane na przykład według ich lokalizacji (Nijakowski 2006, s. 67-80) lub postaw ewentualnych odbiorców (Nijakowski 2006, s. 95-96). Pomniki klasyfikuje się także ze względu na ich formę artystyczną (Grzesiuk-Olszewska 1995).

Traktując miejsca pamięci w najogólniejszym znaczeniu (a zatem jako formy materialne oraz wyimaginowane fenomeny historyczne), możemy rozważać problem upamiętniania w szerszym spektrum problemowym, w którym miejsce pamięci, zamiast niezmiennej i statycznej formy materialnej, staje się dynamiczną rzeczywistością uzależnioną od społecznego kontekstu, przechodzącą przez wiele stadiów istnienia. W takiej sytuacji niezbędnym warunkiem poznania jest nieustanne badanie tego kontekstu, odwoływanie się do świadomości jednostek i grup społecznych, które miejsca pamięci kreują lub są ich depozytariuszami, na przykład z racji ich przejęcia po innych zbiorowościach.

Przedmiotem upamiętnienia są (lub mogą być) wydarzenia lub postaci udokumentowane $\mathrm{w}$ źródłach historycznych, a także te ze świata mitu. Jedne mogą być łatwo i powszechnie identyfikowane, inne pozostają wręcz na marginesie pamięci zbiorowej lub są nierozpoznawane. Nietrudno dostrzec, że miejsce pamięci cieszące się dobrą rozpoznawalnością i znajdujące wsparcie w materialnym upamiętnieniu może przestać istnieć fizycznie i pozostać jedynie w świadomości tych, którzy nadal pamiętają. I odwrotnie, materialna forma może $z$ czasem stać się pustą skorupą, zapomnianą niezrozumiałą formą, za którą nie stoi żadna żywa pamięć. Kluczowe znaczenie ma zatem pytanie, jak klasyfikować i jak sytuować miejsca pamięci ze względu na pozycję $\mathrm{w}$ swoistym procesie upamiętnia- 
nia, a także ze względu na obecność i rozpoznawalność w świadomości odbiorców?

Przed przystąpieniem do odpowiedzi na to pytanie należy zasygnalizować dwie kluczowe kwestie.

Po pierwsze, należy brać pod uwagę realnie istniejący porządek ideologiczno-prawny, który zawsze ma duże (choć nie bezwzględne i bezwyjątkowe) znaczenie dla jakichkolwiek form kreowania pamięci. Opisane przez George’a Orwella realia całkowitego panowania władzy nad pamięcią przeszłości stanowią typ idealny, dotychczas jedynie projektowany w sferze literackiej. Nawet $w$ państwach totalitarnych istniały furtki pozwalające omijać nadzór nad wieloma zastrzeżonymi dla państwa obszarami pamięci lub zdarzały się $\mathrm{w}$ tym względzie zwykłe niedopatrzenia. Przykładem może być Wrocław w okresie III Rzeszy, gdzie - mimo niezwykle ostrej weryfikacji - przez wiele lat zachowały się „niearyjskie” nazwy ulic, których genezy narodowi socjaliści nie dostrzegli lub nie potrafili wytropić (Kruszewski 1996, s. 253-254). Także państwa demokratyczne starają się nadzorować procesy upamiętniania i wpływać na tworzony wizerunek przeszłości wspólnoty, co wynika ze znaczenia pamięci w procesach tożsamościowych i legitymizujących władzę polityczną (Szacka 2006, s. 47-58). Na przykład ewentualne próby upamiętniania podejmowane przez mniejszości narodowe mogą trafiać na opór, nierzadko generując ostre konflikty o pamięć. W Polsce całościową politykę nadzoru nad procesami upamiętniania sprawuje państwo - do 2017 roku poprzez Radę Ochrony Pamięci Walki i Męczeństwa i jej wojewódzkie komitety, obecnie - te same komitety, lecz w ramach Instytutu Pamięci Narodowej. Zmiana ta dokonana $\mathrm{w}$ okresie rządów PiS - choć $\mathrm{w}$ praktyce wygenerowała rozliczne niepotrzebne problemy i spotkała się z dezaprobatą wielu urzędników zaangażowanych dotychczas w upamiętnianie - nie była dziełem przypadku i nie miała charakteru kosmetycznego. Wzmocniła nadzór nad symbolicznym naznaczaniem przestrzeni państwa. Celem nadzoru ze strony instytucji państwowych nie jest bynajmniej tylko unikanie symbolicznego lub estetycznego chaosu. Najważniejsze uzasadnienie wynika z chęci nadzoru nad „domeną symboliczną” wspólnoty, to znaczy nad „[...] terytorium, na którym dana grupa (etniczna, narodowa, regionalna, kulturowa itp. [...] panuje symbolicznie [...]. Granice domeny symbolicznej nie muszą się pokrywać z granicami domeny politycznej" (Nijakowski 2006, s. 108-109). Ponieważ nawet najlepszy nadzór nie jest bezwzględnie szczelny, zawsze istnieją luki umożliwiające dokonanie wyłomu w oficjalnym systemie. W tym przypadku nie chodzi tylko o upamiętnienia nielegalne, których najjaskrawszym i budzącym zwykle silne emocje przy- 
kładem są upamiętnienia mniejszości narodowych (Wróblewski 2007). Przykładem na nieszczelność systemu nadzoru upamiętniania bywają także miejsca pamięci odziedziczone po dawnych systemach ideologicznych, które $\mathrm{z}$ różnych względów przetrwały i $\mathrm{w}$ nierozpoznanej postaci istnieją w szacie krajobrazowo-urbanistycznej, być może czekając na ponowne odczytanie. Przykład może stanowić choćby kamień-pomnik na część Otto von Bismarcka w mazurskich Nakomiadach, którego odkrycie w 2005 roku wygenerowało problem nie tyle oceny niemieckiego kanclerza, ile przede wszystkim - stosunku do kulturowego dziedzictwa tych ziem i ich dawnych mieszkańców (Traba 2009, s. 101-108).

Po drugie, zaproponowane rozumienie miejsc pamięci sprawia, że przedmiotem rozważań stają się nie tylko potencjalne i jeszcze nieistniejące upamiętnienia, lecz także te istniejące realnie, choć poza oficjalnie zaakceptowanym prawnie porządkiem przestrzenno-symbolicznym. Oznacza to potrzebę uwzględniania takich indywidualnych form pamięci jak murale, znaki religijne, kapliczki, miejsca zgromadzeń wspólnot, czyli wszelkie formy, w których żyje pamięć zbiorowa, nawet najmniejszych wspólnot. Jest to tym ważniejsze, że czasem nawet najbardziej marginalne sytuacje i oddolne upamiętnienia mogą zapoczątkować proces oficjalnego upamiętniania lub pobudzić aktywność w sferze kreowania pamięci (Magry, Sánchez-Carretero 2011). Skutkuje to koniecznością uwzględniania potencjalnie nieograniczonej liczby miejsc pamięci, spośród których materialnego upamiętnienia doczekają się wszak tylko nieliczne. Kwestie te należy rozpatrywać w kontekście selektywności pamięci ludzkiej, kluczowej dla tej problematyki. „Aby coś zapamiętać — pisze Aleida Assmann (2013, s. 86) - trzeba zapomnieć, ale to, co zostaje zapomniane, niekoniecznie musi przepaść na zawsze". To, co zapamiętane, ma zatem szansę znaleźć się w kanonie, który - jako wyraz tożsamości zbiorowej - jest najtrwalszą częścią kultury. To w nim zbiorowości lokują swą reprezentatywną kulturę (Kłoskowska 1996, s. 59). Jak nietrudno dostrzec, niewiele miejsc pamięci ma możliwość znalezienia się w ścisłym i dobrze identyfikowanym kanonie pamięci, o którym wiedza w danej wspólnocie jest obowiązująca (Szpociński 2014, s. 182-183) — w sferze rozpoznawalności, przynajmniej przez większą część jej członków. Wsparcie w postaci istniejącego realnie materialnego upamiętnienia (np. pomnika lub muzeum) nieporównywalnie zwiększa szansę na trwanie w świadomości odbiorców, choć nietrafiona formuła (niejasna forma pomnika, nudna ekspozycja muzealna) może uczynić też wiele, by stało się odwrotnie. Warto w tym miejscu przywołać koncepcję kanonu i archiwum Aleidy Assmann. Według niej proces „włączania do kanonu” wspólnoty jest rygorystyczny, zapewnia jednak ,trwałe 
miejsce w pracującej pamięci kulturowej społeczeństwa" (Assmann 2013, s. 76-78). Ze względu na ograniczoność pamięci ludzkiej tylko niewiele miejsc pamięci może wejść do kanonu wspólnoty (narodowej, lokalnej, religijnej itp.). Daleko posunięta selekcja jest konieczna, gdyż tylko wtedy zapewnia się dobrą rozpoznawalność tych elementów, które w kanonie się znalazły. To, co znajduje się poza kanonem, obejmuje bierna pamięć magazynująca - archiwum, czyli „fundament tego, co może być w przyszłości powiedziane, gdy ta stanie się już przeszłością" (Assmann 2013, s. 81).

\section{SCHEMAT ANALITYCZNY}

Przedstawiam tu schemat obrazujący stadia kształtowania się i przemian miejsc pamięci, który pomaga wstępnie zanalizować cztery modelowe sytuacje. Ukazują one swoistą ścieżkę, szereg następujących po sobie stadiów, przez które przechodzą miejsca pamięci. Przy czym udziałem jednych staje się każde $z$ tych stadiów, a innych tylko niektóre.

Stadia kształtowania się i przemian miejsc pamięci (opracowanie własne)
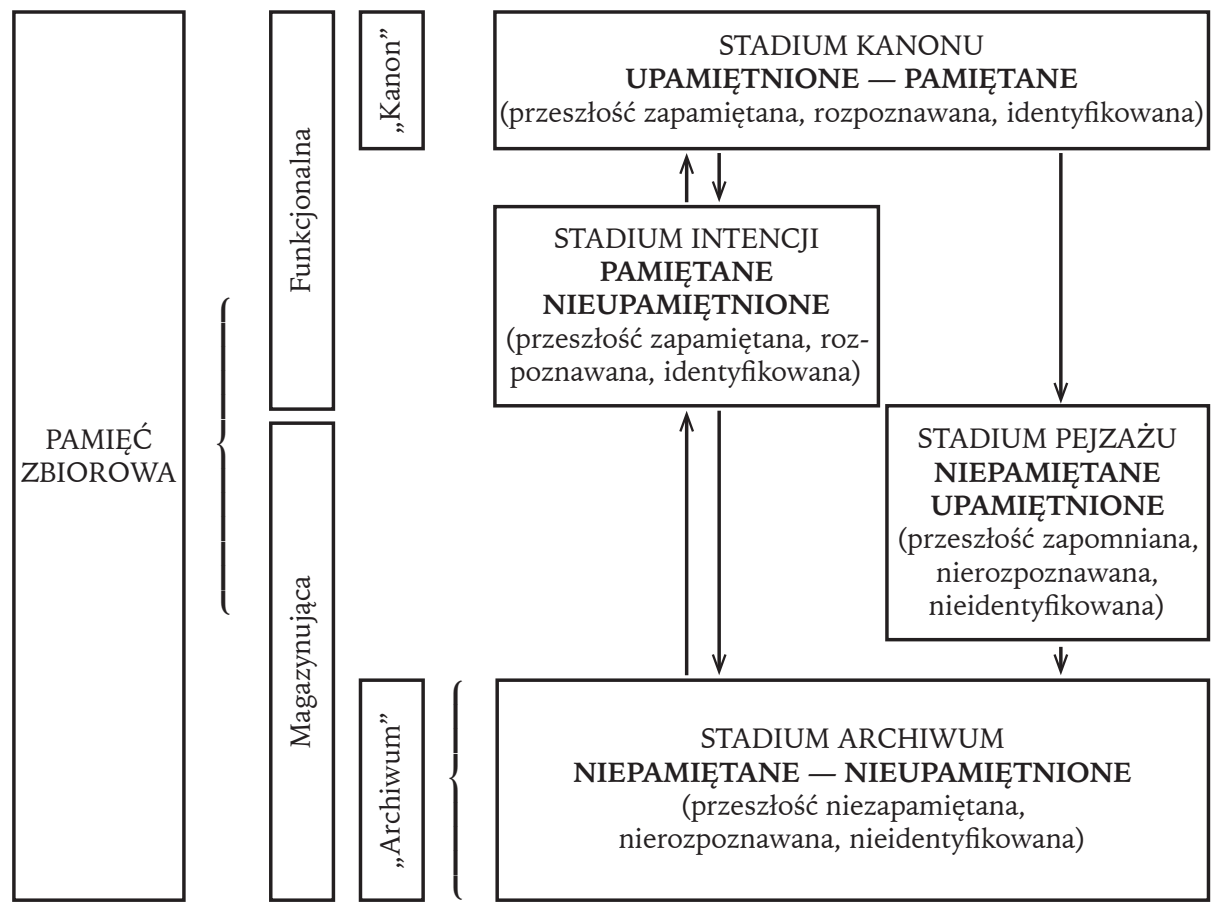

Najobszerniejszym depozytem miejsc pamięci jest obszar przeszłości niepamiętanej i nieupamiętnionej. Obejmuje on sytuacje, w których prze- 
szłość pozostaje nieupamiętniona $\mathrm{w}$ przestrzeni społecznej i jest zatarta w świadomości jej członków. Potencjalnie jest jednak nadal dostępna za sprawą obecności w pamięci kulturowej. Nawiązując do koncepcji Aleidy Assmann można obszar ten określić jako „stadium archiwum” z tym zastrzeżeniem, że zawiera on nie tylko zasoby ściśle „archiwalne” — czyli zarejestrowane $\mathrm{w}$ archiwach zapisy. Stadium to obejmuje najszerszą gamę miejsc pamięci, które są niezapamiętane, nierozpoznawane, nieidentyfikowane i jednocześnie w sensie materialnym nieupamiętnione. Nie budzą też one, co zrozumiałe, społecznych emocji. Nie oznacza to, że te miejsca pamięci (postaci, wydarzenia, symbole i inne wytwory kultury) są bezpowrotnie zapomniane. Dla niemal wszystkich członków wspólnoty (czasem z wyjątkiem wąskiego grona lub pojedynczych specjalistów) są zwykle niedostępne i nie stanowią przedmiotu większego zainteresowania. Tę na pozór zawierającą sprzeczność sytuację można zobrazować odwołaniem do historii pewnego dokumentu. Raport Karla Jägera powstał u schyłku 1941 roku i odnotował mord na 137346 Żydach na Litwie dokonany między lipcem a listopadem 1941 roku przez niemiecką jednostkę policji i służby bezpieczeństwa przy pomocy litewskich kolaborantów (Klee, Dressen, Riess 1991, s. 46-58). Ów 16-stronicowy, niezwykle pedantyczny dokument, odkryty dwie dekady po wojnie w sowieckim archiwum, wymienia kilkadziesiąt miejsc dokonanych zbrodni, które w dużej większości — co dla tego przypadku jest kluczowe - nie doczekały się jakichkolwiek, nawet śladowych upamiętnień, a najczęściej nie funkcjonują nawet w pamięci lokalnych wspólnot żyjących dziś obok miejsc zbrodni (Vanagaitė, Zuroff 2017). Archiwa, biblioteki czy prywatne zbiory zawierają ślady wielu takich miejsc pamięci, które mogą być odkryte. Asumptem bywa często „rewanż pamięci”. Szczególnie wiele przykładów ku temu daje powojenna historia odkrywania Zagłady Żydów, a także innych ludobójstw, które jak Wandea, zbrodnie na Ormianach czy Polakach na Wołyniu — za sprawą impulsu (książka, film, działalność aktywnej jednostki) zostają wydobyte i przywrócone pamięci, gdy wydawały się dla niej bezpowrotnie utracone.

Funkcjonowanie miejsca pamięci w stadium archiwum nie jest stanem ostatecznym. Odbywając podróż tropem przywołanego raportu dokumentującego zagładę litewskich Żydów, poznając realnie istniejące, choć zapomniane i nieupamiętnione przestrzenie Zagłady, można uruchomić proces przejścia miejsca pamięci w kolejne stadium - gdy nie jest wprawdzie jeszcze w żaden oficjalny sposób upamiętnione, lecz wchodzi w obszar pamięci funkcjonalnej, istotnej i ważnej, przynajmniej dla aktywnie społecznej jednostki lub grupy. Gdy pamięć nie znajduje jeszcze swej materialnej formy, pojawia się jednak intencja, by stan ten zmienić. 
Zanim jakiekolwiek miejsce pamięci powstanie, zarówno w materialnej i zaaprobowanej, jak i nielegalnej i sprzecznej z prawem formie, funkcjonuje w stadium „intencji” - zamiaru uczynienia zeń elementu symbolicznego pejzażu określonej domeny politycznej. Sytuacja, w której miejsca pamięci są $\mathrm{w}$ jakimś stopniu utrwalone i zapamiętane $\mathrm{w}$ pamięci zbiorowej wspólnoty, która dąży do jego upamiętnienia, to w pewnym sensie stadium przejściowe w przypadku każdego zapamiętanego zdarzenia, postaci lub symbolu, przed jego oficjalnym upamiętnieniem. Czasami takie miejsce pamięci nie może odnaleźć swego materialnego wyrazu i za sprawą barier polityczno-ideologicznych musi pozostać w świadomości pamiętającej je wspólnoty. W jednym przypadku jest to stan chwilowy, w innym trwa znacznie dłużej, czasem pozostaje na zawsze. Często można wyznaczyć bardzo precyzyjne granice czasowe trwania tego stadium. Ilustrującym tę sytuację przykładem może być masakra stoczniowców wybrzeża. Pomiędzy grudniem 1970 a grudniem 1980 wydarzenie to nie mogło być upamiętnione, pozostawało w „zawieszeniu”, jedynie w pamięci tych, którzy wbrew systemowi ostatecznie doprowadzili do bezprecedensowego upamiętnienia tej zbrodni, jeszcze w okresie komunistycznym.

Przywołany przykład pokazuje, że zjawisko takie często występuje w systemach, które starają się kontrolować przeszłość i narzucać własną wizję historii, jeśli oficjalne wyobrażenie historii zderza się z oddolną i nieoficjalną pamięcią. Ale dzieje się tak w każdym ustroju i sytuacja ta dotyczy każdego miejsca pamięci, różny jest jedynie okres trwania tego stadium. Formą upamiętnień w tym stadium są upamiętnienia oddolne i tymczasowe, często w miejscu tragicznych wydarzeń, będące wyrazem zbiorowego żalu, towarzyszące czasom niepokojów społecznych i traumy. To, co spontaniczne, często, choć nie zawsze, może przerodzić się w oficjalne i zinstytucjonalizowane miejsce pamięci (Magry, Sánchez-Carretero 2011).

Podobnie jak z pomnikiem ofiar Grudnia 1970 roku było z pamięcią Katynia przed 1989 rokiem. Niemożność upamiętnienia ofiar stalinowskiej zbrodni znajdowała wyraz w różnego typu nieoficjalnych, tropionych i często niszczonych przez komunistyczną służbę bezpieczeństwa formach pamięci (np. Dolinka Katyńska na warszawskich Powązkach). Wyjątkiem pozostawał tu Zachód, gdzie pomniki katyńskie stały się elementem pejzażu symbolicznego Londynu, Toronto czy Johannesburga jeszcze w latach siedemdziesiątych-osiemdziesiątych XX wieku. Dzięki przemianom 1989 roku Katyń z miejsca pamięci funkcjonującego w stadium intencji mógł przekształcić się w element ścisłego kanonu pamięci narodowej, jedno z częściej upamiętnianych wydarzeń polskiej historii. 
Jak wspomniano, liczba miejsc funkcjonujących w kanonie pamięci (narodowej, regionalnej, lokalnej) nie może być zbyt duża, a selekcja do kanonu jest rygorystyczna. To stadium obejmuje najbardziej kanoniczne elementy pamięci każdej wspólnoty. Mogą to być wydarzenia lub postaci $z$ przeszłości utrwalone, zapamiętane i dobrze identyfikowane $\mathrm{w}$ świadomości społecznej i pamięci zbiorowej (względnie wśród jakiejś znaczącej części wspólnoty), relatywnie dobrze identyfikowane oraz upamiętnione $\mathrm{w}$ przestrzeni symbolicznej. W przypadku pamięci narodowej Polaków z pewnością miejscami takimi są między innymi: Grób Nieznanego Żołnierza, były obóz zagłady Auschwitz, Westerplatte, pomnik Małego Powstańca i po 1989 roku Katyń. Niektóre z nich (jeśli odnosiły się do walk z Niemcami) tolerowano $\mathrm{w}$ różnym stopniu także w okresie PRL. Nie dotyczyło to już jednak na przykład odzyskania niepodległości w 1918 roku. Choć z podręczników czy innych wytworów kultury nie można było wydarzenia tego usunąć, podejmowano wiele prób manipulacji i wymazywania go $z$ pamięci. Dziś znajduje się już w ścisłym kanonie historii narodowej (Kwiatkowski 2018). Generalnie bardzo pomocne w rekonstrukcji listy takich miejsc są kanony kulturowe (historyczne, literackie), tworzone przez specjalistów, uznawane za „węzły pamięci” wspólnoty narodowej (Najder i in. 2014), lub kanony funkcjonujące w pamięci zbiorowej członków danej wspólnoty, które można bliżej poznać na przykład dzięki badaniom sondażowym (Kwiatkowski 2008; Malicki 2018). Kanony takie zresztą wzajemnie się warunkują i oddziałują na siebie. Tego typu miejsca pamięci w obszarze kanonu mogą występować także na poziomie mniejszych wspólnot. Wówczas są elementem kanonu regionalnego lub lokalnego.

Kanoniczne obrazy upamiętnień funkcjonują w powszechnej zbiorowej pamięci, lub przynajmniej w przeważającej jej części, gdyż - jak zauważa Andrzej Szpociński (2011, s. 75-76): „Osobnik, któremu nic nie mówi nazwisko Mickiewicz, dla którego Grunwald jest nazwą pustą, nawet jeżeli urodził się w Polsce i mówi po polsku, zostanie uznany za specyficznego, bo nieuświadomionego członka wspólnoty narodowej”. Kanony są (a przynajmniej powinny być) stosunkowo dobrze rozpoznawane także w sferze ikonografii, choć pytaniem dla badaczy na przyszłość jest to, w jakim stopniu mediatyzacja poznawania historii i ogólnie poznawanie jej częściej poprzez obraz, rzadziej zaś przez treść, ukształtuje ikoniczny obraz przeszłości w dobie niepodzielnego panowania internetu. A także jakie obrazy przeszłości uznawane za ikoniczny kanon historii będą rozpoznawane i uznawane za istotne przez kolejne pokolenia (np. obrazy Matejki, Grottgera albo zdjęcia Chrisa Niedenthala). 
Funkcjonowanie miejsca pamięci w sferze kanonu (podobnie jak archiwum lub intencji) nie jest zagwarantowane raz na zawsze. Za przykład może służyć okres PRL, w którym władzy komunistycznej udało się wygenerować, wprawdzie niewielki, lecz w pewnym stopniu utrwalony w społecznej pamięci kanon własnych „świętych”. Rok 1989 ujawnił jego kruchość i nietrwałość. Postacie takie jak gen. Karol Świerczewski, choć obecne w kanonach historycznych Polaków okresu PRL (Kwiatkowski 2008, s. 241, 261-262), zniknęły ze świadomości społecznej wkrótce po zmianie ustroju, a ostatecznie wyburzenie najsłynniejszego związanego $\mathrm{z}$ generałem miejsca pamięci — pomnika w Jabłonkach pod Baligrodem nie wywołało już szczególnych emocji, nawet w bieszczadzkich gminach, korzystających na tym miejscu pamięci już jedynie pod względem turystycznym.

Osobliwe jest, że szczególnie liczna kategoria komemoracyjna obejmuje prawdopodobnie miejsca pamięci, które są wprawdzie upamiętnione, lecz z czasem zostały zapomniane lub charakter upamiętnienia stał się dla członków zbiorowości nieznany bądź po latach zupełnie niejasny — to stadium pejzażu, funkcjonowania w pejzażu wspólnot jedynie jako element doświadczanego codziennie krajobrazu, mijanego i nieidentyfikowanego z żadną przeszłością, czasem wręcz z przypisanym przez członków zbiorowości zgoła innym znaczeniem. Wydawać by się mogło, że najlepszymi przykładami miejsc pamięci znajdujących się $\mathrm{w}$ tym stadium są ciągle istniejące, spotykane gdzieniegdzie, nieremontowane i niszczejące obeliski „utrwalaczy władzy ludowej”, stare cmentarze poniemieckie czy żydowskie lub zapomniane obeliski odziedziczone po Niemcach na Ziemiach Odzyskanych. Tymczasem w stadium tym funkcjonować mogą, paradoksalnie, nawet upamiętnienia o doskonałym stopniu rozpoznawalności. Za przykład może posłużyć Pomnik Walk Rewolucyjnych w Rzeszowie, największy istniejący w Polsce komunistyczny obelisk zbudowany ku uczczenia „rewolucyjnych tradycji regionu” oraz tych, którzy ten system utrwalali (w tym także funkcjonariuszy Urzędu Bezpieczeństwa z Rzeszowszczyzny, co podkreślano w dokumentach przy jego powstawaniu, a o czym dzisiejsi jego obrońcy starają się nie pamiętać). Badania sondażowe rzeszowian z 2018 roku wykazały, że choć jest on dobrze znany wszystkim poddanym badaniu ośmiuset respondentom (w dużej części nawet pod poprawną nazwą), to około 95\% mieszkańców stolicy Podkarpacia nie potrafiło wyjaśnić, co rzeczywiście upamiętnia ten obelisk lub co znaczą owe „rewolucyjne walki” (Malicki 2019). Ów paradoks upamiętnienia bez pamięci dotyczy zapewne znacznie większej liczby znanych pomników, które $z$ racji swych gabarytów i lokalizacji (jak wspomniany rzeszowski pomnik) 
wydają się bardzo dobrze rozpoznawane i funkcjonujące w kanonie pamięci różnych zbiorowości. Temat ten wymaga wielu dodatkowych badań i ukazuje, jak pozorna jest siła pomnika, który dla wspólnoty niewiele znaczy, gdy jest przez kogoś narzucony lub jego istnienie nie wynika z rzeczywistych potrzeb społeczności.

W analizie tego stadium niezbędne jest przywołanie pojęcia nie-miejsca, które nawiązuje do sytuacji przestrzeni pozbawionej pamięci. Ten niejednoznaczny termin, różnorodnie interpretowany na obszarze antropologicznej refleksji nad przeszłością i tożsamością (Czapliński 2014), w najbardziej popularnym ujęciu Marca Augé określa przestrzenie tranzytowe i tym samym pozbawione pamięci, stanowiące przeciwstawieństwo miejsc, analogicznie do przeciwstawienia obozu przejściowego miejscu zamieszkania czy bezkolizyjnego skrzyżowania skrzyżowaniu, na którym dochodzi do „spotkania” (Augé 2008, s. 136). „To przestrzeń — pisze Augé (2008, s. 128) - której nie da się określić ani jako tożsamościowej, ani znajomej, ani historycznej”. Dodaje przy tym, że „miejsce i nie-miejsce są raczej ulotnymi biegunami” (Augé 2008, s. 129). Pomijając literacką i trudną w operacjonalizacji formułę tych porównań (Czaja 2013), można sądzić, że utożsamianie tranzytowości z brakiem pamięci przynosi zbyt wiele wyjątków od tak skonstruowanej reguły. Choć autor odnosi swe uwagi do nadnowoczesności, która według niego wytwarza w szczególny sposób tego typu przestrzenie, odwołanie do przeszłości pokazuje, że właśnie punkty przejściowo-,,tranzytowe” z czasem zyskują szczególną rangę w budowaniu pamięci, a przynajmniej dzieje się tak w przypadku wydarzeń tragicznych. Przykłady to choćby Zagłada, warszawski Umschlagpatz, Izbica, Drancy - dziś symbole, choć nawet one spełniały różne funkcje i nigdy nie były jedynie miejscem „tranzytu”. W literaturze można zetknąć się także $z$ inną definicją, według której nie-miejsca to „miejsca tragicznych wydarzeń, ale także te elementy przestrzeni, które są następstwem aktów eksterminacji: porzucone wioski, puste place, zdewastowane cmentarze" (Sendyka 2017, s. 6). Wydaje się, że także w przypadku tej definicji pojęcie nie-miejsca jest zbyt nieostre i ma zbyt dużą liczbę desygnatów pozwalających badaczowi terenowemu dokonywać użytecznych klasyfikacji. Zawiera bowiem przestrzenie upamiętnione i nieupamiętnione funkcjonujące na obrzeżach lub poza pamięcią wspólnot, w których istnieją. W tym sensie obiekty z kategorii nie-miejsc sytuują się raczej pomiędzy miejscami pamięci w stadium archiwum i pejzażu.

Stadia intencji i kanonu możemy odnieść do pamięci określanej przez Aleidę Assmann (2009, s. 128) jako pamięć funkcjonalna lub „zamieszkana". Jej główną funkcją jest formowanie i utrwalanie tożsamości. Wymaga 
ona także nieustannych praktyk i rytuałów (Saryusz-Wolska 2014, s. 325-326). Stadium archiwum i pejzażu można usytuować w obrębie pamięci „niefunkcjonalnej” lub - za Aleidą Assmann (2009, s. 128) - pamięci magazynującej i „drugiego stopnia”, która „absorbuje to, co utraciło żywy związek z teraźniejszością". Miejsca pamięci mogą zatem istnieć, materialnie lub nie, zmieniając jedynie stadium, w którym funkcjonują. Stadium to określa także stan świadomości tych, którzy są ich odbiorcami. Klasyfikacja takich miejsc musi być poprzedzona badaniami społecznymi.

\section{PODSUMOWANIE}

Wszystkie cztery wyróżnione stadia stanowią swoiste typy idealne. Podział ten oczywiście nie obowiązuje bezwyjątkowo. Często mamy do czynienia z sytuacjami pośrednimi. Na przykład jakieś upamiętnione wydarzenie, choć zapomniane, funkcjonuje w świadomości bardzo niewielkiej liczby osób i jest tylko przez nie identyfikowane. Czasami w wyniku dokonanego już upamiętnienia dana przestrzeń „przechodzi” z jednej kategorii do drugiej. Jeśli upamiętnienie nie wynika $z$ realnych potrzeb wspólnoty, to może w ogóle nie znaleźć się w jej kanonie. Sytuację tę należy zapewne odnieść do miejsc pamięci o Zagładzie Żydów, wszak obecnych w przestrzeni symbolicznej Polski, lecz najczęściej słabo identyfikowanych i rozpoznawanych. Miejsca takie bywają bowiem tworzone nie z rzeczywistej potrzeby „pamiętania dla upamiętnienia”, lecz „pamiętania, żeby dać spokój i zapomnieć" (Michlic 2011). Pamięć zbiorowa jako zjawisko dynamiczne (choć także w ograniczonym zakresie) dopuszcza w tej materii różne warianty zmian. Mimo to omówiona ścieżka przeobrażeń miejsc pamięci pozwala na stosunkowo przejrzystą klasyfikację — pod warunkiem odwołania się do świadomości wspólnot, w których miejsca takie funkcjonują i realizacji badań umożliwiających „pomiar” w tej materii.

Tworzenie materialnych miejsc pamięci najczęściej przynależy do prerogatyw władzy i realizowane jest przez specjalistów od przeszłości, urbanistów i artystów, aktywne jednostki. Często się zdarza, że upamiętnienie poświęcone jakiejś postaci lub wydarzeniu poprzez swą niezręczną i nazbyt profesjonalnie określoną formułę jest dla odbiorców źródłem diametralnie różniących się skojarzeń i treści (czego dobrym przykładem znów może być wspomniany rzeszowski pomnik). Wiele miejsc pamięci istnieje dla mijających je każdego dnia jednostek jedynie jako element krajobrazu, nieidentyfikowana $z$ niczym, czasem zapomniana dekoracja przestrzeni. „Bez względu na walory artystyczne i poziom rzeźbiarskiego wykonania pomnik zrasta się na trwałe $\mathrm{w}$ wyobraźni mieszkańców z ich miastem. 
Codzienne z nim obcowanie, w konsekwencji przyzwyczajenie, utrudnia lub wręcz uniemożliwia jego obiektywny osąd" (Hübner-Wojciechowska 1986, s. 110). Problem ten dotyczy nie tylko rozpoznawania przesłania miejsca pamięci i identyfikowania go z konkretną treścią, wydarzeniem lub postacią z przeszłości, lecz nierzadko wynika także z sytuacji „innej obecności i nadmiaru" miejsc pamięci (Skórzyńska 2007, s. 92-93) czy z estetycznej formuły utrudniającej odczytanie przekazu. Konsekwencją tego stanu rzeczy jest sytuacja, w której miejsca pamięci (najczęściej pomniki, choć nie tylko) traktowane są jako swoisty finał procesu upamiętniania, choć powstały obiekt powinien być początkiem aktywnego kreowania procesu pamięci.

$\mathrm{Na}$ materialne wyrazy pamięci (zamierzone, planowane lub już istniejące) często zwracamy uwagę dopiero w sytuacjach konfliktowych — sporu o symbolikę, przekaz, rodowód twórców. Najważniejsze jest zapewne to, że materialna forma upamiętnienia nie określa jego charakteru na zawsze. Przedstawione sytuacje pokazują, że klasyfikacja poszczególnych miejsc pamięci nigdy nie jest ostateczna. To, co dziś znajduje się w obszarze identyfikowanego, dobrze rozpoznawanego kanonu, w przyszłości może ten kanon opuścić, znaleźć się na peryferiach pamięci, a nawet zejść w sferę archiwalnego depozytu, w którym będzie domeną nielicznych specjalistów i zostanie odkryte podczas eksploracji archiwalnej, bibliotecznej lub prac archeologicznych. To, jak długo miejsce pamięci znajduje się w określonym stadium swego istnienia, zależy od wielu czynników, choć z pewnością kluczowa rola przypada zawsze „pracy pamięci”, uczestnictwu w „żywych” jej formach i przedstawieniach.

\section{BIBLIOGRAFIA}

Assmann Aleida, 2009, Przestrzenie pamięci. Formy i przemiany pamięci kulturowej, tłum. Piotr Przybyła, w: Magdalena Saryusz-Wolska (red.), Pamięć zbiorowa i kulturowa. Wspótczesna perspektywa niemiecka, Universitas, Kraków.

Assmann Aleida, 2013, Między historia a pamięcią. Antologia, Wydawnictwo Uniwersytetu Warszawskiego, Warszawa.

Augé Marc, 2008, Nie-miejsca. Wprowadzenie do antropologii hipernowoczesności. Fragmenty, tłum. Adam Dziadek, „Teksty Drugie”, nr 4 (112).

Bachmann-Medick Doris, 2012, Cultural Turns: nowe kierunki w naukach o kulturze, tłum. Krystyna Krzemieniowa, Oficyna Naukowa, Warszawa.

Bednarek Stefan, Korzeniewski Bartosz, 2014, Polskie miejsca pamięci. Dzieje toposu wolności, Narodowe Centrum Kultury, Warszawa.

Czaja Dariusz, 2013, Nie-miejsca. Przybliżenia, rewizje, w: Dariusz Czaja (red.), Inne przestrzenie, inne miejsca. Mapy i terytoria, Wydawnictwo Czarne, Wołowiec. 
Czapliński Przemysław, 2014, Nie-miejsce, w: Magdalena Saryusz-Wolska, Robert Traba (red.), Modi Memorandi. Leksykon kultury pamięci, Scholar, Warszawa.

François Etienne, Hagen Schulze (red.), 2001, Deutsche Erinnerungsorte, t. 1-3, Beck, München.

Le Goff Jacques, 2007, Historia i pamięć, tłum. Anna Gronowska, Joanna Stryjczyk, Wydawnictwa Uniwersytetu Warszawskiego, Warszawa.

Grzesiuk-Olszewska Irena, 1995, Polska rzeźba pomnikowa w latach 1945-1995, Wydawnictwo Neriton, Warszawa.

Hübner-Wojciechowska Joanna, 1986, Społeczno-artystyczne warunki powstawania pomników w Polsce w latach 1945-1980, Instytut Kultury, Warszawa.

Hahn Hans Henning, Traba Robert, 2015, O czym (nie) opowiadaja polsko-niemieckie miejsca pamięci, w: Robert Traba, Hans Henning Hahn (red.), Polsko-niemieckie miejsca pamięci, t. 1: Wspólne/oddzielne, Scholar, Warszawa.

Huyssen Andreas, 1995, Twilight Memories: Marking Time in a Culture of Amnesia, Routledge, New York-London.

Kaźmierska Kaja, 2012, Wspótczesna pamięć komunikacyjna i kulturowa. Refleksja inspirowana koncepcją Jana Assmanna, w: Elżbieta Hałas (red.), Kultura jako pamięć. Posttradycjonalne znaczenie przeszłości, Nomos, Kraków.

Klee Ernst, Dressen Willi, Riess Volker, 1991, The Good Old Days: The Holocaust as Seen by Its Perpetrators and Bystanders, Free Press, New York.

Kłoskowska Antonina, 1996, Kultury narodowe u korzeni, Wydawnictwo Naukowe PWN, Warszawa.

Kończal Kornelia, 2013, Miejsca pamięci. O niebywałej karierze pewnej koncepcji badawczej, w: Robert Traba, Hans Henning Hahn (red.), Polsko-niemieckie miejsca pamięci, t. 4: Refleksje metodologiczne, Scholar, Warszawa.

Kruszewski Tomasz, 1996, Zmiany nazw ulic we Wroctawiu w latach III Rzeszy, w: „Studia nad Faszyzmem i Zbrodniami Hitlerowskimi”, t. XIX, Wydawnictwo Uniwersytetu Wrocławskiego, Wrocław.

Kula Marcin, 2002, Nośniki pamięci historycznej, Wydawnictwo DiG, Warszawa.

Kwiatkowski Piotr Tadeusz, 2008, Pamięć zbiorowa społeczeństwa polskiego w okresie transformacji, Scholar, Warszawa.

Kwiatkowski Piotr Tadeusz, 2018, Odzyskanie niepodległości w polskiej pamięci zbiorowej, Narodowe Centrum Kultury, Warszawa.

Magry Peter Jean, Sánchez-Carretero Cristina, 2011, Rethinking Memorialization: The Concept of Grassroots Memorials, w: Peter Jean Magry, Cristina Sánchez-Carretero (red.), Grassroots Memorials: The Politics of Memorializing Traumatic Death, Berghan Books, New York

Malicki Krzysztof, 2018, Kanony historyczne polskiej młodzieży. Zmiana czy kontynuacja?, w: Zuzanna Bogumił, Andrzej Szpociński (red.), Stare i nowe tendencje w obszarze pamięci społecznej, Scholar, Warszawa.

Malicki Krzysztof, 2019, „Upamiętnianie bez pamięci. Pomnik Walk Rewolucyjnych na Rzeszowszczyźnie w (nie)pamięci mieszkańców stolicy Podkarpacia” (prezentacja z wynikami badań sondażowych dla Urzędu Miasta, materiał niepublikowany).

Michlic Joanna B., 2011, „Pamiętanie dla upamiętnienia”, „pamiętanie dla korzyści” i „pamiętanie, żeby dać spokój i zapomnieć”: różne modele pamięci o Żydach w postkomunistycznej Polsce, „Kultura i Społeczeństwo", nr 4. 
Najder Zdzisław, Machcewicz Anna, Kopczyński Michał, Kuźniar Roman, Sienkiewicz Bartłomiej, Stępień Jerzy, Włodarczyk Wojciech, 2014, Węzły pamięci niepodległej Polski, Fundacja Węzły Pamięci, Muzeum Historii Polski, Znak, Kraków-Warszawa.

Nijakowski Lech M., 2006, Domeny symboliczne. Konflikty narodowe i etniczne w wymiarze symbolicznym, Scholar, Warszawa.

Nijakowski Lech M., 2008, Polska polityka pamięci. Esej socjologiczny, Wydawnictwa Akademickie i Profesjonalne, Warszawa.

Nora Pierre, 2002a, Lére de la commémoration, w: Pierre Nora (red.), Les lieux de mémoire, t. 3, Gallimard, Paris.

Nora Pierre, 2002b, Entre mémoire et Histoire. La problématique des lieux, w: Pierre Nora (red.), Les lieux de mémoire, t. 1, Gallimard, Paris.

Olick Jeffrey K., Robbins Joyce, 2014, Badania nad pamięcia społeczną: od „pamięci zbiorowej” do socjologii historycznej praktyk pamięciowych, w: Kornelia Kończal (red.), (Kon)teksty pamięci. Antologia. Narodowe Centrum Kultury, Warszawa.

Saryusz-Wolska Magdalena, 2011, Spotkania czasu z miejscem. Studia o pamięci i miastach. Wydawnictwa Uniwersytetu Warszawskiego, Warszawa.

Saryusz-Wolska Magdalena, 2014, Pamięć funkcjonalna. w: Magdalena Saryusz-Wolska, Robert Traba (red.), Modi memorandi, Leksykon kultury pamięci, Scholar, Warszawa.

Saryusz-Wolska Magdalena, Traba Robert, 2014, Wprowadzenie, w: Magdalena Saryusz-Wolska, Robert Traba (red.), Modi Memorandi. Leksykon kultury pamięci, Scholar, Warszawa.

Sendyka Roma, 2017, Nie-miejsca pamięci. Elementarz, w: Nie-miejsca pamięci. Elementarz, Ośrodek Badań nad Kulturami Pamięci, Kraków.

Skórzyńska Izabela, 2007, Inscenizacje pamięci: misteria nieobecności w Lublinie, w: Izabela Skórzyńska, Christine Lavrence, Carl Pépin (red.), Inscenizacje pamięci, Wydawnictwo Poznańskie, Poznań.

Stryjek Tomasz, 2014, Francja-Niemcy-Polska-... Polskie badania pamięci a wyzwanie opracowania historii Europy Wschodniej na drugim poziomie, „Kultura i Społeczeństwo”, nr 3.

Szacka Barbara, 2006, Czas przeszty, pamięć, mit, Scholar, Warszawa.

Szpociński Andrzej, 1983, Kanon historyczny. Pamięć zbiorowa a pamięć indywidualna, „Studia Socjologiczne", nr 4.

Szpociński Andrzej, 2011, Antoniny Kłoskowskiej koncepcja kultury narodowej jako źródto inspiracji, „Kultura i Społeczeństwo”, nr 2-3.

Szpociński Andrzej, 2014, Kanon historyczny, w: Magdalena Saryusz-Wolska, Robert Traba (red.), Modi memorandi. Leksykon kultury pamięci, Scholar, Warszawa.

Traba Robert, 2009, Przeszłość w teraźniejszości. Polskie spory o historię na początku XXI wieku, Wydawnictwo Poznańskie, Poznań.

Vanagaitė Rūta, Zuroff Efraim, 2017, Nasi. Podróżując $z$ wrogiem, tłum. Krzysztof Mazurek, Wydawnictwo Czarna Owca, Warszawa.

Wawrzyniak Joanna, 2014, Pamięć zbiorowa, w: Magdalena Saryusz-Wolska, Robert Traba, (red.), Modi memorandi. Leksykon kultury pamięci, Scholar, Warszawa.

Wróblewski Piotr, 2007, Mobilizacja i konflikt etniczny. Miejsca święte mniejszości narodowych w Polsce, Semper, Warszawa.

Żakowski Jacek, 2002, Rewanż pamięci, Sic!, Warszawa. 


\title{
BETWEEN THE CANON AND THE ARCHIVE: \\ ON THE SYSTEMATIZATION AND CLASSIFICATION OF MEMORIAL SITES
}

\author{
Krzysztof Malicki \\ (University of Rzeszów)
}

\begin{abstract}
The final element in acommemoration process is often considered to be a memorial plaque, monument, or museum. However, what precedes the creation of these material forms, or what happens to their message after they disappear or ${ }^{\text {. }}$. are transferred to the periphery of public interest, is often the most interesting * for a researcher. The purpose of this article is to systematize and classify different forms of memorial sites by treating them as material and imaginary historical phenomena. By referring to the concept of functional and storage memory, as well as ${ }^{\circ}$. to Aleida Assman's concepts of the canon and the archive, the article presents the ${ }^{*}$. stages in the production of memorial sites: from the first idea, through creation, to the moment when they cease to existor are obliterated from the collective consciousness.
\end{abstract}

key words: collective memory, memorial sites, storage and functional memory, canon, archive

słowa kluczowe: pamięć zbiorowa, miejsca pamięci, pamięć magazynująca i funkcjonalna, kanoni archiwum 